\title{
The essence of culture diversity in family businesses from Mexico and Poland
}

\author{
Ewa Więcek-Janka ${ }^{1}$ \\ ${ }^{1}$ Poznan University of Technology, Poznan, Poland \\ *ewa.wiecek-janka@put.poznan.pl
}

\begin{abstract}
The present paper is the description of research on differences in the influence of family aspects on the functioning of family businesses in two cultural contexts: low and high. High-context culture was represented by family businesses from Mexico and low-context by family businesses from Poland. The research was conducted using a structured individual interview with family business owners. The results obtained point to a strong relationship of values and family aspects with the operation of a family business. It may therefore be assumed that the influence of family aspects on the functioning of family businesses in different cultural contexts is similar, both in Poland (low-context) and Mexico (high-context).
\end{abstract}

Keywords: Cultutal Context in Management, Family Business, Cultural Differences.

\section{Introduction}

There have been many attempts to give a precise definition of culture. Yet, the most popular and adequate definition to date seems to be the one by Hofstede, who defines it as the collective programming of the mind distinguishing the members of one group from others $[1,2,3,6]$. Hofstetde [6] presents in his work the psychological dimensions of culture. He underlines that each group has their own unique culture, whose role is to maintain its coherence at both macro and micro levels. Culture forms the foundations of collective identity. Collective identity shapes feelings and values connected with the sense of intergenerational continuity, memory of the past and the notion of mutual destiny $[2,3,4]$. The pursuit of the research aim makes it necessary to look at the classification of cultures from a variety of perspectives, which entails a brief characterization of selected culture classifications. The first approach discussed refers to the social structure and way in which messages are expressed and conversations are run [4, 5, 10, 11, 12, 13]. Hall [5] in his work specifies two cultural paradigms (contexts): high and low. In his opinion, Asian, Arabic, Mediterranean cultures as well as the people of South and Central America represent high cultural context. In such a context, non-verbal communication prevails and is highly valued in people as it is believed that body language establishes the context of a conversation. It is essential for people brought up in such a culture to maintain interpersonal relations, especially family relations, which often affects steps taken and decisions made in the business sphere. Being convinced of group power, and not power of an individual, is of particular importance in making decisions and taking group initiatives. Relationships between employers and employees are perceived as personal and in companies in those countries one can spot strong bonds between employees, regardless of positions held. It is particularly important to set up direct contact and become engaged in conversation, which abounds in gesticulation, touching the interlocutor, etc. [7].

Countries representing the American, German, Swiss or Scandinavian groups are considered to be low-context cultures. They also cover Northern Europe countries, including Poland. People of these cultures communicate literally, unequivocally, and expect others to say what they think and think what they say $[2,8]$ They approach conversations in concrete terms and are thoroughly prepared for business meetings. Verbal communication is valued more than body language. Professional duties are separate from interpersonal relations and the work environment is formalized.

Another division concerns an approach connected with the ability to cooperate. Striving for individualism and collectivism illustrates the relations which culture is characterized by according to Reynolds and Valentine [7]. In North America, most Northern and Western European countries, one highly values individualism, independence and self-sufficiency, which is testimony to individualistic 
cultures. Children are taught autonomy, independent thinking and expressing themselves, asking questions at school, making choices as well as accepting responsibility for their own decisions and deeds $[3,7,9,10]$. All activities and decisions taken in collectivistic cultures originate in a group. Collectivism is popular in Africa, Asia, the Middle East, Central and South America, partly in Australia and Oceania. Children are brought up to respect senior family members, drawing from them useful values. Differences in the approach are featured in table 1.

Individualistic cultures bring up leaders - individuals capable of dealing with problems, respecting privacy and personal zone. Countries of collectivistic culture, on the other hand, instill into their citizens a conviction that there is a strong interdependency between individuals. Therefore, it is important to form a group and respect and develop interpersonal relations. Hierarchical upbringing teaches distance, respect and being subjected to and dependent on superior individuals. It is often connected with the position held in a given social group, e.g. in an enterprise, family, group of peers. The consequences of not being acquainted with the cultural context and approach to individualism and collectivism may lead to a number of misunderstandings and conflicts. International enterprises should be aware of cultural distinctiveness, which they will have to face during the process of internationalization. Table 1 contains the summary of deliberations concerning the classification of cultures.

Table 1. Summary of the general classification and perception of culture

\begin{tabular}{|c|c|}
\hline \multicolumn{2}{|c|}{$\begin{array}{c}\text { Intercultural communication } \\
\text { SUMMARY }\end{array}$} \\
\hline $\begin{array}{c}\text { NORTH AMERICA, } \\
\text { NORTHERN AND WESTERN EUROPE, AUSTRALIA }\end{array}$ & $\begin{array}{c}\text { MEDITERRANEAN COUNTRIES, AFRICA, THE MIDDLE EAST, CENTRAL AND } \\
\text { SOUTH AMERICA }\end{array}$ \\
\hline Individualism & Collectivism \\
\hline Focus on achievements & Focus on relations \\
\hline Competitiveness & Indirectedness \\
\hline Directedness & Lenient treatment of time \\
\hline Strict treatment of time & Context is important \\
\hline Content is important & Non-linear logic \\
\hline Linear logic & Hierarchical structures \\
\hline Flat cultures & Believing in the power of silence \\
\hline Believing in the power of words & Solving disputes through mediation \\
\hline Solving disputes in court & \\
\hline
\end{tabular}

Source: Reynolds\&Valentine, 2009.

From the point of view of organization and logic, more populous societies are difficult to be democratically organized, which is conducive to creating the system of hierarchization $[2,3]$. The assigned persons adopt the role of leaders of people. It is easier in smaller groups to distribute responsibilities and solve problems in a democratic way.

\section{Data and Methodology}

The research was conducted in two populations of family businesses: Poland and Mexico. The population units were family business owners from both countries. The survey method used was an Internet questionnaire. The interviews were carried out in 111 Mexican enterprises and 154 Polish enterprises. The research was carried out between 10 November 2015 and 30 April 2016. The sample distribution is presented in table 2 . 
Table 2. Structure of the research sample

\begin{tabular}{|c|c|c|c|}
\hline \multicolumn{2}{|c|}{ Sample structure } & Poland $(\mathrm{n}=154)(\%)$ & $\operatorname{Mexico}(\mathrm{n}=111)(\%)$ \\
\hline Company size & $\begin{array}{c}\text { Micro (up to 9) } \\
\text { Small (10-49) } \\
\text { Medium (50-249) } \\
\text { Large (more than 250) }\end{array}$ & $\begin{array}{c}68 \\
28 \\
2,6 \\
0,64\end{array}$ & $\begin{array}{c}73,87 \\
19,81 \\
5,4 \\
0,9\end{array}$ \\
\hline Branch & $\begin{array}{l}\text { Production } \\
\text { Trade } \\
\text { Service } \\
\text { Multi-branch }\end{array}$ & $\begin{array}{c}11,68 \\
16,88 \\
43,5 \\
27,9\end{array}$ & $\begin{array}{c}0,72 \\
56,75 \\
29,72 \\
6,3\end{array}$ \\
\hline $\begin{array}{l}\text { Mangement } \\
\text { generation }\end{array}$ & $\begin{array}{l}\text { First } \\
\text { Second } \\
\text { Third } \\
\text { Fourth }\end{array}$ & $\begin{array}{c}70,12 \\
25,32 \\
3,8 \\
0,65\end{array}$ & $\begin{array}{c}63,96 \\
27,02 \\
8,1 \\
0,9\end{array}$ \\
\hline $\begin{array}{l}\text { Succession } \\
\text { plans }\end{array}$ & $\begin{array}{c}\text { Lack } \\
\text { I do not know } \\
\text { YES, without action } \\
\text { YES, with the action }\end{array}$ & $\begin{array}{c}3,24 \\
17,53 \\
23,37 \\
55,2\end{array}$ & $\begin{array}{c}3,6 \\
11,7 \\
14,4 \\
70,27\end{array}$ \\
\hline $\begin{array}{c}\text { Geografical } \\
\text { basis of activity }\end{array}$ & $\begin{array}{l}\text { Local } \\
\text { Regional } \\
\text { National } \\
\text { Global }\end{array}$ & $\begin{array}{l}38,96 \\
27,27 \\
23,37 \\
10,38\end{array}$ & $\begin{array}{c}72,97 \\
17,11 \\
9 \\
0,9\end{array}$ \\
\hline
\end{tabular}

Source: authors' own elaboration.

Family businesses covered by the research represented diverse business lines. The analysis of this category points to Polish enterprises dominating in the following business lines: manufacturing $(12 \%)$, service $(44 \%)$ and multi-business $(28 \%)$. Mexican enterprises dominate in the trade sector $(57 \%)$.

The analysis of the length of time businesses are in operation indicates one essential difference. In Poland, the number of enterprises aged 11-25 is twice as high as in Mexico (Poland 31\%, Mexico $15 \%$ ). Such a result is connected with the systemic changes in Poland after 1989, which should imply research into the identification of variables responsible for the future of the said firms in this category of enterprises.

It is also interesting to see lack of essential differences in remaining populations connected with the length of time a family business operates on the market. Such a result may indicate the emergence of identical specific characteristics of family enterprises and their ability to shape longevity.

The identification of succession intentions in enterprises of both countries shows that the share of family businesses acting for succession in both countries is the highest and amounts to $70.3 \%$ in Mexico and to $55.5 \%$ in Poland.

Another source of comparison was the area affected by the operation of family businesses in both countries. As it can be concluded from the presented data, family businesses in Mexico in a large part (73\%) operate on the local market, whereas the share of Polish family businesses amounts to $39 \%$. $27 \%$ of Polish businesses declared their operational area to be local and global while Mexican firms operating in the similar context amounted to only $10 \%$. The geographical scope of influencing the market is connected with the cultural context. In high-context culture (Mexico), relations are established with the local environment and cooperation between family businesses is nurtured. Leading to the creation of cooperatives, Polish family businesses realize market activities being close to low-context culture, which facilitates formal communication at the international level.

The qualitative analysis of the collected research material points to several significant differences between features describing family businesses in Poland and Mexico in relation to cultural context. They include: the impact of the market; intention to pass a firm over to next generation; the business line in which a firm operates. 
The interviews were recorded and the results were entered into an Excel spreadsheet, which was the basis for further analyses.

The main research problem was to perform a comparison of features responsible for shaping family's business responsibility by business families functioning in contrasting cultural contexts: Mexican in high-context culture and Polish in low-context culture. It was assumed, in accordance with Halls' approach [2,5], that Mexican enterprises are characterized by high context and collectivistic culture, which results in a more increased influence of values, norms and traditions on business decisions than it is the case with Polish enterprises.

Despite significant and widely described cultural differences between Poland and Mexico, the author of the paper indicated in other analyses [3], that family-related features impact business behaviour more that cultural context does. Thus, she recognizes that there is a contextless element merging two areas of family business functioning, which she refers to as Business Responsibility of the Family. Its model is illustrated in figure 1.

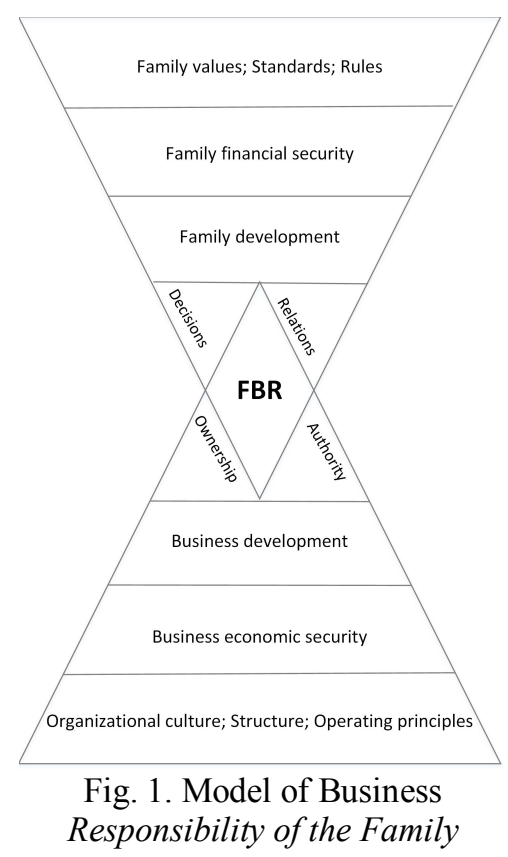

\section{Results and Discussion}

The research covered the main hypothesis: In family enterprises functioning in different cultural contexts, there will not be essential differences in the evaluation of components of business responsibility of the family. Null hypotheses were made assuming lack of differences between family enterprises in the range of the following:

H1 - decisions are made consciously in the family taking into account the development of an enterprise;

$\mathrm{H} 2$ - exercising authority in an enterprise takes into account the developmental needs of family members;

H3 - good relations in the family are good relations in an enterprise;

H4 - the ownership of an enterprise takes into account family members' interests in the long-term perspective.

Each hypothesis was coupled with the null hypothesis stating that there are no differences between analyzed enterprises in two cultural contexts and with alternative ones stating that there are such differences.

For the verification of the hypotheses, $t$ test was used for independent samples and the adopted significance level was $\alpha=0.05$. The raw data was tabulated and processed using Statistica software. The results are shown in table 3. 
Table 3. Results of testing detailed hypotheses

\begin{tabular}{|c|c|c|c|c|c|c|c|c|c|c|c|}
\hline \multirow{2}{*}{$\begin{array}{c}\text { Poland } \\
\text { vs Mexico }\end{array}$} & \multicolumn{10}{|c|}{ T test for independent samples, alfa=0,1 } \\
\cline { 2 - 12 } & $\begin{array}{c}\text { Average } \\
\text { Poland }\end{array}$ & $\begin{array}{c}\text { Average } \\
\text { Mexico }\end{array}$ & $\mathrm{t}$ & $\mathrm{df}$ & $\mathrm{p}$ & $\begin{array}{c}\mathrm{N} \\
\text { Poland }\end{array}$ & $\begin{array}{c}\mathrm{N} \\
\text { Mexico }\end{array}$ & $\begin{array}{c}\text { Standard } \\
\text { Deviation } \\
\text { Poland }\end{array}$ & $\begin{array}{c}\text { Standard } \\
\text { Deviation } \\
\text { Mexico }\end{array}$ & $\begin{array}{c}\text { Quotient } \mathrm{F} \\
\text { Variances }\end{array}$ & $\begin{array}{c}\mathrm{p} \\
\text { Variances }\end{array}$ \\
\hline $\mathrm{H} 1_{0}$ & 3,772 & 3,702 & 0,539 & 263 & 0,590 & 153 & 111 & 0,960 & 1,148 & 1,431 & 0,040 \\
\hline $\mathrm{H} 2_{0}$ & 3,928 & 3,954 & $-0,207$ & 263 & 0,835 & 153 & 111 & 1,016 & 1,021 & 1,009 & 0,951 \\
\hline $\mathrm{H} 3_{0}$ & 3,883 & 3,747 & 1,071 & 263 & 0,288 & 153 & 111 & 1,009 & 1,031 & 1,056 & 0,747 \\
\hline $\mathrm{H} 40$ & 3,285 & 3,559 & $-2,015$ & 263 & 0,044 & 153 & 111 & 1,019 & 1,157 & 1,252 & 0,195 \\
\hline
\end{tabular}

Source: authors' own elaboration

The application of $t$ test allows to ascertain that there are no grounds for rejecting null hypotheses for: $\mathrm{H} 1, \mathrm{H} 2$ and $\mathrm{H} 3$. It may mean that in case of:

1.making decisions in the family which take into account business sphere needs,

2.exercising power in an enterprise which takes into account family members' needs,

3.the influence of relations in the family on relations in an enterprise,

there are no essential differences between family enterprises in Poland and Mexico. The distribution of $t$ test for the analyzed hypotheses is illustrated in figures $2,3, \mathrm{i} 4$.

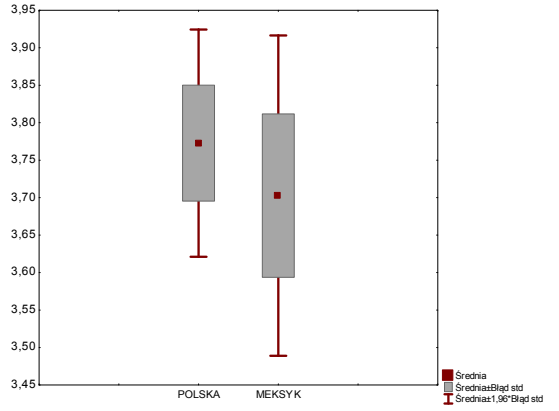

Fig. 2. Distribution of $t$ test results for $\mathrm{H} 1$ hypothesis

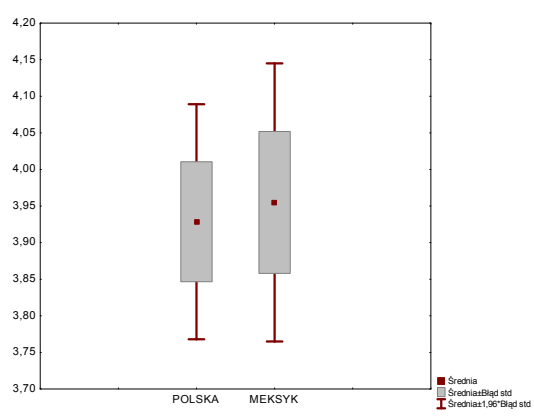

Fig. 3. Distribution of $t$ test results for $\mathrm{H} 2$ hypothesis

The obtained t test parameters for $\mathrm{H} 4$ allow to reject the null hypothesis in order to adopt the alternative hypothesis and ascertain that there are differences between enterprises in Poland and Mexico in the range of the influence of the ownership of a family business on meeting family members' needs in the long-term perspective. The adoption of the alternative hypothesis indicates the influence of the cultural context in the analyzed range (cf. fig. 10). Mexican enterprises rated aspects connected with planning the distribution of ownership and preparation for succession more highly. It is more common in these companies to talk about the distribution of ownership, inheritance and taking over responsibilities than it is the case with Polish enterprises, where unwillingness to talk about ownership, distribution of assets, money and succession is stressed.

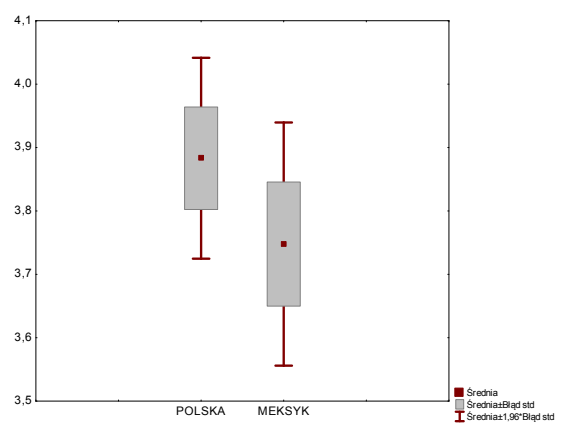

Fig. 4. Distribution of $t$ test results for $\mathrm{H} 3$ hypothesis

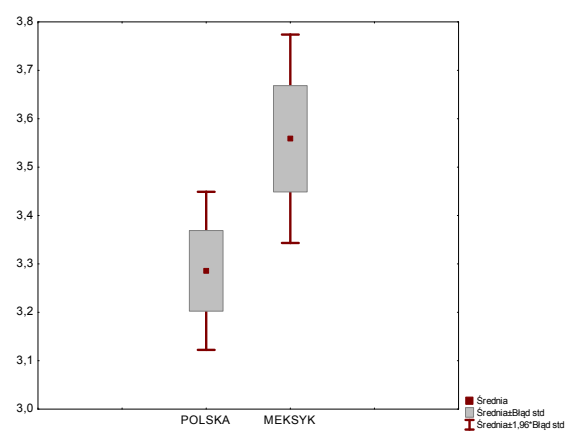

Fig. 5. Distribution of $t$ test results for $\mathrm{H} 4$ hypothesis

The analysis allowed to look at the distribution of results for the obtained medians in the assessment of four features of business responsibility of the family. Medians in H1 distributions point to a higher evaluation of Polish family firms in the range of the family's conscious decision-making processes 
for the sake of enterprise development. Medians in the test distribution for $\mathrm{H} 2$ show a slight advantage of Mexican enterprises, which attests to making use of authority in an enterprise to meet family members' needs. Medians in H3 distribution indicate greater differences. It means that the influence of family relations on relations in an enterprise is more highly rated in Mexico than in Poland. The greatest difference between median results in the analyzed samples were recorded for $\mathrm{H} 4$, which was about the influence of ownership in an enterprise on meeting family members' needs in the long-term perspective (fig. 5).

\section{Conclusion}

The performed qualitative and quantitative analyses allow to state that the analyzed family enterprises in Poland and Mexico are subject to the influence of cultural context (external impact) and family aspects as an internal feature of family enterprises. The obtained results point to a strong influence of values and family aspects on the operation of a family business. Both in Polish and Mexican enterprises, one can observe lack of essential differences in the emergence of three analyzed aspects of business responsibility of the family: decision-making processes, interpersonal relations and authority. The fourth of the analyzed features - ownership of an enterprise is differently understood and implemented in business practice in countries of contrasting cultural contexts, which was proven using $\mathrm{t}$ test for independent groups.

The research was carried out on low samples, not securing the representative character of the population of respondents. Nonetheless, the obtained results seem to be promising and conducting research with the higher representativeness of family businesses as well as widening its scope by including additional countries of low- and high-context culture will allow to perform a more in-depth analysis of the issue.

\section{References}

[1] J.W. Berry: Global psychology: implication for cross-cultural research and management, International Journal of Cross Cultural Management, vol. 22, (3), (2015), p. 342-355.

[2] P. Boski: Five meanings of integration in acculturation research. International Journal of Intercultural Relations, 32 (92), (2008), p. 142-153.

[3] E. Więcek-Janka, M. R. Contreras Loera, J. Kijewska and G. Tirado: Family and business in family enterprises in countries of low and high-context cultures - research conducted using grey system theory: (2016 in press).

[4] D. Pinto: Intercultural communication, Garant, Leuven (2000).

[5] E. Hall, M. Hall: Understanding Cultural Differences. Intercultural Press, Yarmouth, ME (1990).

[6] G. Hofstede, G. J. Hofstede: Cultures and Organizations: Software of the Mind. 2nd Edition, McGraw-Hill USA (2005).

[7] S. Reynolds, D. Valentine: Guide to cross-cultural communication, 2nd edn, Pearson Education, Upper Saddle River, New York (2011).

[8] V. Bennet-Martinez, F. Lee and J. Leu: Biculturalism and cognitive complexity: Expertise in cultural representations. Journal of Cross-Cultural Psychology, 37 (4) (2006) p. 386-407.

[9] M.H. Bond: Working at the interface of cultures: 18 lives in social science, Routledge, London (1997).

[10] R.W. Brislin, T. Yoshida: Intercultural communication training: An introduction, Sage, Thousand Oaks (1994).

[11] A. Furnham, S. Bochner: Culture shock: Psychological reactions to unfamiliar enviroments, Metheun, London (1986).

[12] W.B. Gudykunst: Cross-Cultural and intercultural communication, Sage, Thousand Oaks (2003).

[13] A. Hamrol, D.Kowalik, A. Kujawińska, Impact of Selected Work Condition Factors on Quality of Manual Assembly Process, Human factors and eronomics in manufacturing \& service industries, vol. 21, no. 2, (2011), p. 156-163. 